\title{
TINGKAT KOMPETENSI PENGETAHUAN PERPUSTAKAAN BAGI GURU MADRASAH MELALUI DIKLAT SUBSTANTIF PEMBEKALAN PENUGASAN TAMBAHAN CALON KEPALA PERPUSTAKAAN
}

\author{
Samsul Falak*
}

Pengutipan: Falak, S. (2016). Tingkat kompetensi pengetahuan perpustakaan bagi guru madrasah melalui diklat substantif pembekalan penugasan tambahan calon kepala perpustkaan. Jurnal Ilmu Perpustakaan, Informasi, dan Kearsipan Khizanah Al-Hikmah, 4(1), 65-75.

*Widyaiswara di Tenaga Teknis Balai Diklat Keagamaan Semarang

(samsulfalak@kemenag.go.id)

\section{ABSTRAK}

Guru memiliki latar belakang pendidikan keguruan tetapi bisa menjadi kepala perpustakaan. Akan tetapi pengetahuan perpustakaan guru terbatas. Dari peserta yang mengikuti diklat substantif pembekalan penugasan tambahan calon kepala perpustakaan tidak ada yang memiliki latar belakang pendidikan perpustakaan. Oleh karena itu kompetensi pengetahuan tentang perpustakaan bagi calon kepala perpustakaan dari guru menarik untuk diteliti. Diklat substantif pembekalan penugasan tambahan calon kepala perpustakaan bagi guru memberi kesempatan untuk mengetahui sejauh mana guru memiliki kompetensi pengetahuan perpustakaan. Penelitian tentang tingkat kompetensi pengetahuan perpustakaan bagi guru yang akan menjadi kepala perpustakaan dilakukan di Balai Diklat Keagamaan Semarang. Peserta diberikan pre test dan pos test. Dari tes awal atau pre test tentang pengetahuan perpustakaan calon kepala perpustakaan diperoleh $35 \%$ rendah dan $60 \%$ sedang sisanya tinggi. Setelah mengikuti Diklat selama sepuluh hari, peserta diberikan pos test. Hasil pos tes; rendah 0\% sedang 70\% dan tinggi 30\%. Diklat tugas tambahan calon kepala perpustakaan sangat tepat sebagai sarana untuk meningkatkan kompetensi pengetahuan guru yang memiliki tugas tambahan sebagai kepala perpustakaan atau yang akan menjadi kepala perpustakaan. Ini ditunjukan dari hasil penelitian bahwa kompetensi pengetahuan perpustakaan guru mengalami kenaikan yang signifikan.

Kata Kunci: Kepala perpustakaan, Kompetensi pustakawan, Pelatihan kepustakawanan

\section{ABSTRACT}

Teachers do have teaching education backgrounds, but many of them worked as library chief as well even though they do not posses librarianship background. All participants (library school chief candidates) do not have such a background. Hence, the study will research on it. The workshop held by Balai Diklat Keagamaan Semarang is aimed to add librarianship insights for all participants. All parcipants were given pre-test and post-test. From the pre-tes, it is found that $35 \%$ were low and $60 \%$ were in the middle, while the rest were high. Meanwhile, from the post-test the lowest was $0 \%$, middle was $70 \%$, and the highest was $30 \%$ respectively. The workshop is a proper medium to enhance competency for all candidates. It is shown that from the result findings that the knowledge of librarianship was significantly improved.

Key words: Library chief, Librarian competency, Librarianhsip workshop 


\section{PENDAHULUAN}

\section{a. Latar Belakang Penelitian}

Keberhasilan madrasah, selain ditentukan oleh guru, pegawai, dan peserta didik, juga ditentukan adanya kelengkapan sarana dan prasarana. Perpustakaan merupakan salah satu sarana untuk meningkatkan dan mendukung keberhasilan kegiatan belajar mengajar di madrasah. Adanya perpustakaan madrasah adalah hal yang harus tersedia untuk keberadaan madrasah. Hal ini sesuai dengan Peraturan Menteri Penddikan Nasional Republik Indonesia Nomor 24 Tahun 2007 tentang Standar Sarana dan Prasarana hal. 20 bahwa perpustakaan salah satu dari sarana yang dipersaratkan untuk keberadaan sekolah/madrasah. Jadi keberadaan perpustakaan di madrasah tidak bisa ditawar lagi.

Perpustakaan madrasah dianggap sebagai pelengkap. Kalaupun perpustakaan itu ada, banyak perpustakaan yang tidak diurus dengan baik. Jika perpustakaan itu dibenahi dengan benar dan didayagunakan sebagai sumber belajar bagi masyarakat madrasah, maka akan membantu kelancaran kegiatan belajar mengajar.

Perpustakaan bukanlah satu-satunya sumber belajar bagi guru maupun siswasiswi untuk mendapatkan pengetahuan, karena saat ini dengan perkembangan dunia teknologi, pengetahuan bisa didapatkan melalui internet secara mudah. Namun demikian kelebihan perpustakaan tidak terganggu adanya jarak ataupun lokasi terpencil yang tidak bisa terjangkau oleh sinyal internet. Perpustakaan juga tidak terganggu jika kelistrikan padam. Jelas bahwa perpustakaan madrasah sangat penting. Kita sering mendengar bahwa jantung dari suatu negara adalah universitas dan jantung dari universitas adalah perpustakaan. Agar tidak menjadi slogan, hendaknya pengelola tidak berkecil hati dan harus tetap memiliki niatan yang mulia untuk tetap semangat dan mengembangkan madrasah.

Berdasarkan Permendiknas No 25 Tahun 2008 Tentang Standar Tenaga Perpustakan Sekolah/Madrasah, penyelenggara sekolah/madrasah wajib menerapkan standar tenaga perpustakaan Sekolah/Madrasah sebagaimana diatur dalam Peraturan Menteri ini, selambatlambatnya 5 (lima) tahun setelah Peraturan Menteri ini ditetapkan. Setiap sekolah/madrasah untuk semua jenis dan jenjang yang mempunyai jumlah tenaga perpustakaan sekolah/madrasah lebih dari satu orang, mempunyai lebih dari enam rombongan belajar (rombel), serta memiliki koleksi minimal 1000 (seribu) judul materi perpustakaan dapat mengangkat kepala perpustakaan Madrasah.

Kualifikiasi untuk Kepala Perpustakaan Sekolah/Madrasah yang melalui Jalur Pendidik harus memenuhi syarat: a. berkualifikasi serendahrendahnya diploma empat (D4) atau sarjana (S1); b. memiliki sertifikat kompetensi pengelolaan perpustakaan Sekolah/Madrasah dari lembaga yang ditetapkan oleh pemerintah; c. masa kerja minimal 3 (tiga) tahun. Guna menjawab tantangan kemajuan dunia pendidikan perlu diadakan suatu pendidikan dan pelatihan Kepala Perpustakaan Madrasah.

Peningkatan kompetensi Kepala Perpustakaan salah satunya dapat ditempuh melalui pendidikan dan 
pelatihan (diklat). Oleh karena itu, Balai Diklat Keagamaan Semarang sebagai penyelenggara diklat di lingkungan Kementerian Agama yang meliputi daerah Jawa Tengah dan D.I. Yogyakarta memberikan perhatian kepada peningkatan kompetensi kepala perpustakaan, terutama guru yang mendapat tugas tambahan sebagai kepala perpustakaan. Guru memiliki latar belakang pendidikan dibidang keguruan, meski ada yang sudah mengikuti pelatihan, pendidikan Diploma 2. Tetapi dari 30 peserta Diklat Teknis Substantif Pembentukan Calon Kepala Perpustakaan Angkatan 2 tahun 2015 tidak satupun peserta memiliki latar belakang pendidikan perpustakaan.

Berdasar penjelasan di atas, penulis tertarik untuk melakukan penelitian tentang "Tingkat Kompetensi Pengetahuan Perpustakaan bagi Guru Madrasah melalui Diklat Substantif Pembekalan Penugasan Tambahan Calon Kepala Perpustakaan". Penelitian ini untuk mengetahui tingkat kompetensi pengetahuan peserta diklat substantif pembekalan penugasan tambahan calon kepala perpustakaan selama 10 hari mengikuti diklat tersebut. UNI Peneliti mengambil pre-testuntuk data awal kemudian di akhir kegiatan diklat peneliti juga mengambil post test sebagai data pembanding untuk mengetahui apakah ada peningkatan kompetensi pengetahun peserta diklat calon kepala perpustakaan.

\section{Berdasar latar belakang dapat} diketahui beberapa masalah yang ada pada uraian di atas adalah sebagai berikut: penataan perpustakaan madrasah masih belum maksimal, guru yang menjadi kepala perpustakaan madrasah memiliki kemampuan manajerial yang masih rendah, guru yang mendapat tugas tambahan sebagai kepala perpustakaan memiliki pengetahuan perpustakaan yang rendah.

\section{b. Rumusan Masalah}

Berdasarkan identifikasi masalah yang telah diuraikan di atas, maka permasalahan dirumuskan "Bagaimana tingkat kompetensi pengetahuan perpustakaan bagi guru madrasah melalui diklat substantif pembekalan penugasan tambahan calon kepala perpustakaan?"

\section{c. Tujuan dan Manfaat Penelitian}

Secara umum tujuan penelitian ini bertujuan untuk mengetahui tingkat kompetensi pengetahuan perpustakaan bagi guru madrasah melalui diklat substantif pembekalan penugasan tambahan calon kepala perpustakaan".

Sementara hasil penelitian ini diharapkan dapat:

dari segi ilmiah, dapat memberi sumbangan pengetahuan dalam bidang penelitian kediklatan yang dilakukan oleh lembaga-lembaga diklat pada umumnya. Dari segi kegunaan atau penerapannya, penelitian ini diharapkan dapat memberikan informasi kepada para pengambil kebijakan di Balai Diklat Keagamaan Semarang, beserta jajarannya dalam rangka upaya membina serta meningkatkan kegiatan kediklatan, memberi saran mengenai langkahlangkah apa yang perlu ditempuh untuk meningkatkan kinerja Widyaiswara Teknis BDK Semarang.

Dalam lingkungan yang lebih luas lagi, hasil penelitian ini apabila perlu dapat digunakan sebagai bahan pertimbangan dalam rangka memerencanakan dan 
menetapkan jalannya pelaksanaan kediklatan pada umumnya.

\section{TINJAUN TEORETIS}

\section{a. Pendidikan dan Pelatihan}

Pendidikan dan pelatihan (diklat) pada hakikatnya merupakan salah satu bentuk kegiatan dari program pengembangan sumber daya manusia (personal development). Pengembangan sumber daya manusia sebagai salah satu mata rantai (link) dari siklus pengelolaan personil dapat diartikan: merupakan proses perbaikan staf melalui berbagai macam pendekatan yang menekankan realisasi diri (kesadaran), pertumbuhan pribadi dan pengembangan diri. Pengembangan mencakup kegiatankegiatan yang bertujuan untuk perbaikan dan pertumbuhan kemampuan (abilities), sikap (attitude), keterampilan (skill), dan pengetahuan anggota organisasi.

Menurut Notoatmodjo (2009:27) diklat selain untuk meningkatkan kemampuan staf yang menduduki suatu jabatan tertentu juga dilakukan untuk meningkatkan produktivitas kerja. Dengan peningkatan produktivitas kerja para pegawai/karyawan organisasi yang bersangkutan akan memperoleh keuntungan. Pendapat Notoatmodjo tersebut menekankan betapa pentingnya diklat bagi pegawai/karyawan dalam proses pencapaian tujuan atau keberhasilan organisasi. Kemampuan dan keterampilan pegawai dipandang sebagai modal yang sangat besar dalam peningkatan produktivitas kerja. Oleh karenanya, diklat merupakan suatu hal yang seharusnya dilaksanakan secara terus-menerus dan berkesinambungan.

Sholihin (2015:14) menyatakan istilah diklat atau pendidikan dan pelatihan digunakan dalam sebuah organisasi dan kenal dengan nama diklat. Berdasarkan Peraturan Pemerintah Nomor 101 Tahun 2000 tentang Pendidikan dan Pelatihan Jabatan Pegawai Negeri Sipil, disebutkan "Pendidikan dan pelatihan Jabatan Pegawai Negeri Sipil yang disebut Diklat adalah proses penyelenggaraan belajar mengajar dalam rangka meningkatkan kemampuan Pegawai Negeri Sipil". Pendidikan dan pelatihan kepegawaian juga merupakan bagian dari sebuah sistem pembinaan karier Pegawai Negeri Sipil yang bermakna pada pengembangan kepegawaian.

Dari beberapa pendapat di atas disimpulkan bahwa diklat adalah serangkaian kegiatan yang didesain untuk meningkatkan pengetahuan, ketrampilan dan meningkatkan sikap, perilaku pegawai negeri sipil dalam menjalankan tugas sehingga tujuan organisasi dapat tercapai.

Pendidikan dan pelatihan sebagai bagian integral dari kebijakan personil dalam rangka pembinaan pegawai disamping sebagai sarana pembinaan yang bertujuan untuk meningkatkan kemampuan teknis, juga untuk memantapkan sikap mental pegawai. Pendidikan dan pelatihan merupakan alat untuk menyesuaikan antara tanggung jawab dan pekerjaan dengan kemampuan, keterampilan dan kecakapan serta keahlian dari pegawai. Kebijaksanaan organisasi pada umumya menyarankan agar setiap pegawai diberi kesempatan untuk melanjutkan pendidikan dan pengembangan kepribadian, sehingga dapat meningkatkan pengetahuan serta keterampilan yang pada akhirnya mampu kompetensi dalam hal ini adalah kepala madrasah. 


\section{b. Kepala Perpustakaan}

Secara garis besar, ruang lingkup tugas kepala perpustakaan dapat diklasifikasikan ke dalam dua aspek pokok, yaitu pekerjaan di bidang administrasi perpustakaan dan pekerjaan yang berkenaan dengan pekerjaan profesionalisme sebagai petugas perpustakaan. Dua hal tersebut harus dimiliki oleh seorang kepala perpustakaan. Kepala perpustakaan sangat dibutuhkan dalam startegi pengembangan perpustakaan. Jika seseorang yang berdedikasi tinggi dan memiliki kemampuan baik manajerial dan pengetahuan di bidang perpustakaan maka perpustakaan bisa berjalan dengan baik meski dalam keterbatasan.

Berdasarkan Permendiknas Nomor 25 Tahun 2008 tentang Standar Tenaga Perpustakaan Sekolah/Madrasah bahwa perpustakaan madrasah memiliki lebih dari satu tenaga perpustakaan yang terdiri dari kepala perpustakaan dan sekurangkurangnya satu tenaga perpustakaan dengan mempunyai lebih dari enam rombongan belajar (rombel), memiliki koleksi minimal seribu judul maka bisa mengangkat tenaga perpustakaan. Kualifikasi kepala perpustakaan sebagai berikut:

\section{1) Kepala Perpustakaan Sekolah/ Madrasah yang melalui jalur pendidik}

Kepala perpustakaan sekolah/madrasah harus memenuhi syarat:

a) Berkualifikasi serendah-rendahnya diploma empat (D4) atau sarjana (S1);

b) Memiliki sertifikat kompetensi pengelolaan perpustakaan sekolah/madrasah dari lembaga yang ditetapkan oleh pemerintah;

c) Masa kerja minimal 3 (tiga) tahun.

2) Kepala Perpustakaan Sekolah/ Madrasah yang melalui Jalur Tenaga Kependidikan

Kepala perpustakaan sekolah dan madrasah harus memenuhi salah satu syarat berikut:

a) Berkualifikasi diploma dua (D2) Ilmu Perpustakaan dan Informasi bagi pustakawan dengan masa kerja minimal 4 tahun; atau

b) Berkualifikasi diploma dua (D2) non-Ilmu Perpustakaan dan Informasi dengan sertifikat kompetensi pengelolaan perpustakaan sekolah/madrasah dari lembaga yang ditetapkan oleh pemerintah dengan masa kerja minimal empat tahun di perpustakaan sekolah/madrasah.

Kepala madrasah bisa mengangkat kepala perpustakaan dari tenaga kependidikan dengan sertifikat kompetensi perustakaan dan telah mengabdi selama tiga tahun. Dasar inilah yang menjadi pegangan pengangkatan seorang kepala perpustakaan madrasah. Jika diteliti lebih lanjut tentang kualifikasi tersebut madrasah tidak sembarang mengangkat kepala perpustakaan dari jalur guru karena harus ada sertifikat kompetensi pengelolaan perpustakaan yang dikeluarkan lembaga resmi. Balai Diklat sebagai lembaga pemerintah tentunya merupakan lembaga resmi yang memberikan pendidikan dan pelatihan. Melihat fakta yang ada atau bukti dari antusiasme guru yang ingin menjadi kepala perpustakaan adalah adanya beberapa proposal dari beberapa satuan 
kerja madrasah yang menginginkan kerjasama penyelenggaraan diklat kepala perpustakaan.

Balai diklat keagamaan semarang secara khusus memang memiliki kewajiban meningkatkan kompetensi pegawai di bawah naungan Kementerian Agama. Oleh karena itu, tepat kiranya jika balai diklat keagamaan semarang mengadakan diklat pembekalan kepala perpustakaan.

\section{c. Kompetensi Pengetahuan}

Menurut Cece Wijaya dan Tabrani Rusyan (1994:7) menjelaskan kompetensi adalah kemampuan yang merupakan gambaran hakikat kualitatif dari perilaku guru atau tenaga kependidikan yang tampak sangat berarti. Hal senada di sampaikan Usman (1995: 14), kompetensi adalah suatu hal yang menggambarkan kemampuan seseorang, baik yang bersifat kualitatif maupun kuantitatif.

Intelektualitas seseorang bisa dilihat dari kompetensi pengetahuan yang mereka miliki melalui hasil penilaian. Peraturan Menteri Pendidikan dan Kebudayaan (Permendikbud) Nomor 66 Tahun 2013 yang telah direvisi menjadi 104 Tahun 2014 tentang Standar Penilaian Pendidikan menjelaskan penilaian pendidikan merupakan proses pengumpulan dan pengolahan informasi untuk mengukur pencapaian pencapaian kompetensi peserta didik yang mencakup: penilaian otentik, penilaian diri, penilaian berbasis portofolio, ulangan, ulangan harian, ulangan tengah semester, ulangan akhir semester, ujian tingkat kompetensi, ujian mutu tingkat kompetensi, ujian nasional, dan ujian sekolah/madrasah. Penilaian pencapaian kompetensi peserta didik mencakup kompetensi sikap, pengetahuan, dan keterampilan yang dilakukan secara berimbang sehingga dapat digunakan untuk menentukan posisi relatif setiap peserta didik terhadap standar yang telah ditetapkan. Penilaian terhadap pengetahuan peserta didik dapat dilakukan melalui tes tulis, tes lisan, dan penugasan. Kegiatan penilaian terhadap pengetahuan tersebut dapat juga digunakan sebagai pemetaan kesulitan belajar peserta didik dan perbaikan proses pembelajaran.

Dari uraian diatas disimpulkan kompetensi pengetahuan adalah kemampuan seorang dalam mengelola bidang tugasnya yang terkait dengan pengetahuan apa yang menjadi pekerjaan dapat di selesaiakan sesuai dengan tujuannya. Jika pengetahuan itu bisa dilihat dari tugasnya maka harapanya adalah seseorang yang memiliki kompetensi pengetahuan mampu menyelesaikan tugas tugas pekerjaan yang diembanya.

\section{METODE PENELITIAN}

\section{a. Desain Penelitian}

Penelitian ini merupakan penelitian kuantitatif sederhana. Karena peneliti memberikan perlakuan terhadap peserta diklat teknis subtantif pembekalan tugas tambahan kepala madrasah dengan melakukan pre-test sebelum kegiatan diklat dimuali dan posttest setelah kegiatan diklat berakhir. Dari nilai pre-test peneliti bisa melihat kemampuan awal peserta diklat tugas tambahan kepala perpustakaan tentang kompetensi pengetahuan perpustakaan dan posttest untuk melihat tingkat kompetensi setelah adanya perlakuan terhadap peserta yaitu pemberian materi tentang perpustkaan selama kediklatan berlangsung sehingga terlihat peningkatan kompetensi 
pengetahuan perpustakaan sebelum dan sesudah mengikuti diklat.

Hasil pre-test dan post-test akan menjadi gambaran awal dan akhir penelitian ini, maka penulis menganggap penelitian ini adalah kuantitatif. Hal ini sesuai dengan yang dikatakan oleh Purwanto (2008:16) bahwa bilangan merupakan bahasa artifisial yang objektif dan tanpa emosi sehingga dipandang tepat untuk mewakili komunikasi penelitian yang menjunjung objektifitas dan netralitas.

\section{b. Populasi}

Menurut Sugiyono (2013:62), populasi adalah wilayah generalisasi yang terdiri atas objek atau subjek yang mempunyai kualitas dan karakteristik tertentu yang ditetapkan oleh peneliti untuk dipelajari dan kemudian ditarik kesimpulannya. Hal ini sesuai sengan pedoman penulisan tesis dan disertasi Program Pasca Sarjana Unnes (2014:17), populasi adalah semua individu atau unit atau peristiwa yang ditetapkan sebagai subyek penelitian yang memiliki karakteristik tertentu dan merupakan wilayahgeneralisasi yang ditetapkan oleh peneliti.

Populasi penelitian ini semua peserta diklat substansi pembekalan tugas pembekalan tugas tambahan kepala perpustakaan angkatan 2 sebagai sampel sekaligus yang berjumlah 30 orang berasal dari Provinsi D.I Yogyakarta dan Provinsi Jawa Tengah.

\section{c. Teknik Pengumpulan Data}

Dalam rangka mendapatkan data-data dari obyek penelitian, diperlukan metode yang tepat digunakan untuk pengumpulan data. Metode yang digunakan dalam penelitian ini adalah metode tes.

Tes adalah serentetan pertanyaan atau latihan serta alat lain yang digunakan untuk mengukur ketrampilan, pengetahuan, intelegensi, kemampuan atau bakat yang dimiliki oleh individu atau kelompok. (Arikunto, 2011:32). Tes adalah sebuah metode untuk mengukur kemampuan seseorang, pengetahuan, atau ketrampilan dalam sebuah bidang yang diberikan. Menurut Djemari Mardapi (2012: 108), metode tes merupakan salah satu bentuk instrumen yang digunakan untuk melakukan pengukuran. Tes terdiri atas sejumlah pertanyaan yang memiliki jawaban benar atau salah, atau semua benar atau sebagian benar. Metode tes ini digunakan untuk memperoleh data tentang hasil belajar atau assesment.

Peneliti menggunakan pre-test dan posttest. Metode tes ini digunakan untuk mengetahui kemampuan pengetahuan awal dan setalah mengikuti diklat substansi pembekalan tugas pembekalan tugas tambahan kepala perpustakaan angkatan 2.

\section{HASIL PENELITIAN DAN PEMBAHASAN}

\section{a. Hasil Pre-test}

Hasil pre-test dan post-test dari peserta maka dengan langkah-langkah yang ditempuh dalam pengambilan 30 peserta yang akan dijadikan sampel dalam penelitian untuk setiap kelasnya adalah sebagai berikut:

1) Berdasarkan hasil rata-rata pre-test dan hasil peserta test sebelumnya, peserta dikelompokkan menjadi 
tiga kelompok, yakni kelompok tinggi, sedang, dan rendah.

2) Berdasarkan hasil rata-rata posttest dan hasil peserta test sebelumnya, peserta dikelompokkan menjadi tiga kelompok, yakni kelompok tinggi, sedang, dan rendah

Hasil pre-test dan post-test yang diperoleh dari peserta diklat dapat di kategorikan sebagai berikut :

Nilai rendah $=x<50$

Nilai Sedang $=50<x<75$

Nilai Tinggi $=x>75$

Dari hasil pre-test dan post-test dapat dilihat pada tabel berikut ini.

Tabel 1. Hasil pre-test

\begin{tabular}{|l|l|c|c|c|}
\hline \multirow{2}{*}{ No } & Nama/ Inisial & \multicolumn{3}{|c|}{ Nilai } \\
\cline { 3 - 5 } & & Betul & Salah & Nilai \\
\hline 1 & Responden 1 & 18 & 22 & $\mathbf{4 5}$ \\
\hline 2 & Responden 2 & 21 & 19 & $\mathbf{5 2 . 5}$ \\
\hline 3 & Responden 3 & 19 & 21 & $\mathbf{4 7 . 5}$ \\
\hline 4 & Responden 4 & 15 & 25 & $\mathbf{3 0}$ \\
\hline 5 & Responden 5 & 20 & 20 & $\mathbf{5 0}$ \\
\hline 6 & Responden 6 & 24 & 16 & $\mathbf{6 0}$ \\
\hline 7 & Responden 7 & 21 & 19 & $\mathbf{5 2 . 5}$ \\
\hline 8 & Responden 8 & 21 & 19 & $\mathbf{5 2 . 5}$ \\
\hline 9 & Responden 9 & 23 & 17 & $\mathbf{5 7 . 5}$ \\
\hline 10 & Responden 10 & 21 & 19 & $\mathbf{5 2 . 5}$ \\
\hline 11 & Responden 11 & 32 & 8 & $\mathbf{8 0}$ \\
\hline 12 & Responden 12 & 22 & 18 & $\mathbf{5 5}$ \\
\hline 13 & Responden 13 & 19 & 21 & $\mathbf{4 7 . 5}$ \\
\hline 14 & Responden 14 & 23 & 17 & $\mathbf{4 6}$ \\
\hline 15 & Responden 15 & 23 & 17 & $\mathbf{5 7 . 5}$ \\
\hline 16 & Responden 16 & 25 & 15 & $\mathbf{6 2 . 5}$ \\
\hline 17 & Responden 17 & 18 & 22 & $\mathbf{4 5}$ \\
\hline 18 & Responden 18 & 8 & 32 & $\mathbf{2 0}$ \\
\hline 19 & Responden 19 & 22 & 18 & $\mathbf{5 5}$ \\
\hline 20 & Responden 20 & 24 & 16 & $\mathbf{6 0}$ \\
\hline 21 & Responden 21 & 18 & 22 & $\mathbf{4 5}$ \\
\hline 22 & Responden 22 & 23 & 17 & $\mathbf{5 7 . 5}$ \\
\hline 23 & Responden 23 & 19 & 21 & $\mathbf{4 7 . 5}$ \\
\hline 24 & Responden 24 & 18 & 22 & $\mathbf{4 5}$ \\
\hline 25 & Responden 25 & 22 & 18 & $\mathbf{5 5}$ \\
\hline 26 & Responden 26 & 21 & 19 & $\mathbf{5 2 . 5}$ \\
\hline 27 & Responden 27 & 23 & 17 & $\mathbf{5 7 . 5}$ \\
\hline 28 & Responden 28 & 25 & 15 & $\mathbf{6 2 . 5}$ \\
\hline 29 & Responden 29 & 19 & 21 & $\mathbf{4 7 . 5}$ \\
\hline 30 & Responden 30 & 26 & 14 & $\mathbf{6 5}$ \\
\hline & & & & \\
\hline
\end{tabular}

Selanjutnya nilai post-test dapat dilihat pada tabel berikut ini. 
Tabel 2. Hasil post-test

\begin{tabular}{|c|c|c|c|c|}
\hline \multirow[t]{2}{*}{ No } & \multirow[t]{2}{*}{ Nama } & \multicolumn{3}{|c|}{ Nilai } \\
\hline & & Betul & Salah & Nilai \\
\hline 1 & Responden 1 & 32 & 8 & 80 \\
\hline 2 & Responden 2 & 33 & 7 & 82.5 \\
\hline 3 & Responden 3 & 27 & 13 & 67.5 \\
\hline 4 & Responden 4 & 34 & 6 & 85 \\
\hline 5 & Responden 5 & 28 & 12 & 70 \\
\hline 6 & Responden 6 & 33 & 7 & 82.5 \\
\hline 7 & Responden 7 & 28 & 12 & 70 \\
\hline 8 & Responden 8 & 28 & 12 & 70 \\
\hline 9 & Responden 9 & 36 & 4 & 90 \\
\hline 10 & Responden 10 & 33 & 7 & 82.5 \\
\hline 11 & Responden 11 & 34 & 6 & 85 \\
\hline 12 & Responden 12 & 31 & 9 & 77.5 \\
\hline 13 & Responden 13 & 29 & 11 & 72.5 \\
\hline 14 & Responden 14 & 37 & 3 & 92.5 \\
\hline 15 & Responden 15 & 33 & 7 & 82.5 \\
\hline 16 & Responden 16 & 32 & 8 & 80 \\
\hline 17 & Responden 17 & 24 & 16 & 60 \\
\hline 18 & Responden 18 & 30 & 10 & 75 \\
\hline 19 & Responden 19 & 29 & 11 & 72.5 \\
\hline 20 & Responden 20 & 35 & 5 & 87.5 \\
\hline 21 & Responden 21 & 33 & 7 & 82.5 \\
\hline 22 & Responden 22 & 31 & 9 & 77.5 \\
\hline 23 & Responden 23 & 30 & 10 & 80 \\
\hline 24 & Responden 24 & 30 & 10 & 80 \\
\hline 25 & Responden 25 & 30 & 10 & 80 \\
\hline 26 & Responden 26 & 28 & 12 & 70 \\
\hline 27 & Responden 27 & 28 & 12 & 70 \\
\hline 28 & Responden 28 & 28 & 12 & 70 \\
\hline 29 & Responden 29 & 34 & 6 & 85 \\
\hline 30 & Responden 30 & 27 & 13 & 67.5 \\
\hline
\end{tabular}

Tabel 3. Kriteria hasil pre-test dan post-test

\begin{tabular}{|l|c|c|}
\hline Kriteria & Pretest & Postest \\
\hline Rendah & 11 & 0 \\
\hline Sedang & 18 & 21 \\
\hline Tinggi & 1 & 19 \\
\hline
\end{tabular}

Tabel diatas menunjukan bahwa perbandingan pre-test dan post-test sangat signifikan. Dalam pre-test; rendah 11 orang sedang posttest nol orang, dan kategori sedang 18 orang dan post-test 21 orang, sedang kategori tinggi; pre-test 1 orang sedang posttest 19 orang. Hasil pretest dan post-test dapat digambarkan dengan diagram grafik batang sebagai berikut.

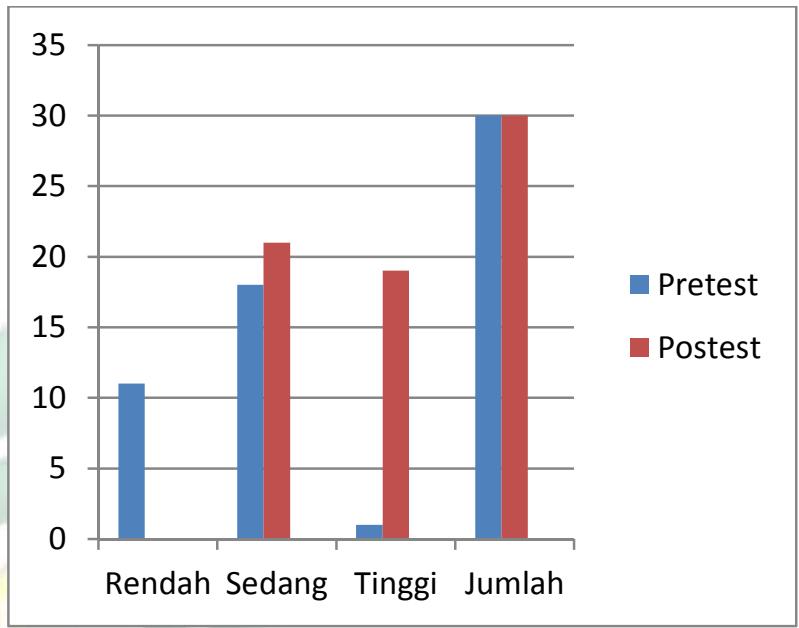

Grafik 1. Hasil pre-test dan post-test

Grafik di atas menunjukan bahwa peningkatan kompetensi pengetahuan meningkat signifikan dan dapat dipresentasekan seperti tabel di bawah ini.

\section{Tabel 4. Kenaikan pre-test dan post-test dalam presentase}

\begin{tabular}{|l|c|c|c|c|}
\hline Kriteria & Pretest & Postest & $\begin{array}{c}\text { Pretest } \\
\text { dalam } \\
\%\end{array}$ & $\begin{array}{c}\text { Postest } \\
\text { dalam } \\
\%\end{array}$ \\
\hline Rendah & 11 & 0 & $36,67 \%$ & $0 \%$ \\
\hline Sedang & 18 & 21 & $60 \%$ & $70 \%$ \\
\hline Tinggi & 1 & 19 & $3,33 \%$ & $30 \%$ \\
\hline
\end{tabular}

Tabel di atas membandingkan persentase hasil pretest dan postest. Hasil pretest menunjukan kriteria rendah $36.67 \%$ sedangkan postest $0 \%$. Kriteria sedang hasil pretest $60 \%$ dan postest $70 \%$ dan kriteria tinggi hasil pretest 3,33\%, 
untuk postes 30\%. Sehingga dapat disimpulkan bahwa peserta diklat substantif pembekalan penugasan tambahan calon kepala perpustakaan memiliki peningkatan kompetensi pengetahuan yang sangat signifikan, bahkan tidak ada satupun peserta yang masih memiliki kemampuan rendah.

\section{KESIMPULAN DAN SARAN}

\section{a. Kesimpulan}

Dari hasil pengolahan dan analisis data yang diperoleh, maka dapat disimpulkan bahwa Guru yang mengikuti Diklat Tugas Tambahan sebagai Kepala Perpustakaan menunjukan peningkatan kompetensi dalam pemahaman perpustakaan, hal ini di tunjukkan dengan membandingkan antara hasil pre-test dan post-test sebagaimana yang telah ditunjukkan pada hasil penelitian sebelumnya.

\section{b. Saran}

Berdasarkan kesimpulan yang diperoleh, penelitian ini dapat memberikan saran sebagai berikut:

1) Guru yang sudah mendapatkan diklat perpustakaan agar terus meningkatkan kemampuan bidang perpustakaan

2) Balai Diklat merencanakn diklat kepala perpustakaan untuk guru yang belum mendapat kesempatan mengikuti diklat perpustakaan

\section{DAFTAR PUSTAKA}

Arikunto, Suharsimi. 2005. Dasar-Dasar Evaluasi Pendidikan. Jakarta: Bumi Aksara

Cece Wijaya dan Tabrani Rusyan. 1994. Kemampuan Dasar Guru Dalam
Proses Belajar Mengajar, Bandung: PT Remaja Rosdakarya.

Mardapi, Djemari. 2012. Pengukuran Penilaian \& Evaluasi Pendidikan. Yogyakarta Nuha Medika

Notoatmodjo, Soekidjo. 2009.Pengembangan Sumberdaya Manusia. Jakarta:Penerbit Rineka Cipta;.

Departemen Agama RI, 2001. KMA No. 1 tahun 2001 Tentang Kedudukan, Tugas, Fungsi, Kewenangan, Susunan Oganisasi dan Tata Kerja Departemen Agama. Jakarta: Badan Litbang dan Diklat Departemen Agama.

Kemendikbud. Peraturan Menteri Pendidikan Nasional Republik Indonesia, Nomor 25, tahun 2008, tentang Standar Tenaga Perpustakaan Sekolah/ Madrasah

Kemendikbud. Peraturan Menteri Pendidikan Nasional Republik Indonesia, Nomor 24, tahun 2007, tentang Standar Sarana dan Prasarana Sekolah/ Madrasah

Kemendikbud. Peraturan Menteri Pendidikan Nasional Republik Indonesia, Nomor 66, tahun 2013, tentang Pendidikan dan Pelatihan Jabatan Pegawai Negeri Sipil.

Presiden Republik Indonesia. Peraturan Pemerintah No 101 tahun 2000, tentang Standar Penilaian Pendidikan.

Purwanto, 2008, Metodologi Penelitian Kuantitatif. Yogyakarta: Pustaka Pelajar.

Sugiyono, 2013. Metode Penelitian Manajemen. Bandung: Alfabeta,

Usman, Moh. Uzer, 1995 Menjadi Guru Profesional, Ed.2, Cet-22, Bandung: PT Remaja Rosdakarya.

Unnes, 2011. Pedoman Penulisan Tesis dan Disertasi Program Sarjana 
Unnes, Semarang: Program Paska Sarjana. 